\title{
Uji Psikomotor Waktu Reaksi pada Siswa yang Sarapan dan Tidak Sarapan
}

\author{
Psychomotor Reaction Time Test for Students Who Ate Breakfast and \\ Skipped Breakfast
}

Rosita Andriani*, Bambang Purwanto ${ }^{1}$, Merryana Adriani²

ABSTRAK

Latar Belakang: Kebiasaan makan yang saat ini dimiliki oleh anak usia sekolah dasar adalah sulitnya untuk makan dengan jumlah yang seharusnya yaitu 3 kali dalam sehari sesuai dengan kebutuhan, salah satunya adalah sarapan. Disaat mereka tidak sarapan sebelum berangkat ke sekolah mereka akan kekurangan asupan energi yang dapat menyebabkan anak tersebut cepat mengalami kelelahan dan kurang konsentrasi dalam menerima pelajaran saat di sekolah. Uji psikomotor waktu reaksi adalah interval antara penerimaan stimulus dengan suatu responyang meliputi perilaku gerakan dan koordinasi jasmani, ketrampilan motorik dan kemampuan fisik seseorang.

Tujuan: Untuk menganalisis hasil uji psikomotor waktu reaksi serta untuk memberikan gambaran mengenai perbedaan waktu reaksi antara siswa yang sarapan dan tidak sarapan

Metode: Penelitian ini merupakan penelitian yang bersifat observasional dengan menggunakan design cross sectional. Sampel dalam penelitian ini adalah anak sekolah usia 9-12 tahun yaitu sebanyak 100 anak dengan cara mengukur waktu reaksi siswa baik yang sudah sarapan atau tidak sarapan dengan alat khusus yaitu Body Reaction

Hasil: Hasil penelitian menunjukkan bahwa sebesar $45 \%$ siswa memiliki kebiasaan sarapan dan sebesar $55 \%$ siswa tidak memiliki kebiasaan sarapan dengan hasil uji psikomotor waktu reaksi antara siswa yang sarapan lebih baik dibandingkan dengan siswa yang tidak sarapan $(p=0,01)$.

Kesimpulan: Terdapat perbedaan uji psikomotor waktu reaksi antara siswa yang sarapan dan tidak sarapan. Sebaiknya siswa menyempatkan sarapan terlebih dahulu sebelum berangkat sekolah, karena dengan sarapan akan memacu pertumbuhan dan memaksimalkan kemampuan di sekolah.

Kata kunci: anak sekolah, sarapan, waktu reaksi

ABSTRACT

Background: One of bad eating habits elementary school age children is their incapability to eat three times a day according to the needs with most of them skipping breakfast. When they didn't have breakfast before they went to school, they will be prone to nutrient deficiency. Lack of energy resulted from skipping breakfast can cause the children to quickly experience fatigue and having less concentration for accepting the lesson at school. Psycomotor test reaction time is the interval between receiving stimulus with a respon do main which includes movement behaviour and physical coordination, motor skills.

Objectives: The purpose of this research was to analyze test time reaction psychomotor and to provide an overview of the time difference reaction between students who ate breakfast and did not eat breakfast

Methods: This study was an observational study using cross sectional design. The sample in this study was school children aged 9-12 years. One hundred children were involved in this study. The measurement of reaction time of students who had breakfast or not breakfastwas done with a special tool called Body Reaction.

Results: The result showed that of $45 \%$ students have a habit of eating breakfast and at $55 \%$ students did not have a habit of eating breakfast. The psychomotor test time reaction between students who ate breakfast was better than the students who did not eat breakfast ( $p=0.01)$.

Conclusions: There was significant difference in psychomotor test time reaction between students who ate breakfast and did not eat breakfast. It is suggested for the students to eat breakfast first before they left to school because the nutrient obtained from breakfast will trigger growth and maximize their learning capability at school.

Keywords: school children, breakfast, reaction time

C 2019. Andriani, et al. Open access under CC BY - SA license.

Received: 05-12-2018, Accepted: 24-1-2019, Published online: 04-03-2019.

doi: 10.20473/amnt.v3.i1.2019.7-12 


\author{
*Koresponden: \\ rositandriani18@gmail.com \\ ${ }^{1}$ Madrasah Ibtidaiyah Islamiyah, Desa Kramat Jegu, 61257, Sidoarjo, Jawa Timur, Indonesia \\ ${ }^{2}$ Departemen Gizi Kesehatan, Fakultas Kesehatan Masyarakat, Universitas Airlangga \\ Kampus C Mulyorejo, 66115, Surabaya, Jawa Timur, Indonesia
}

\section{PENDAHULUAN}

Sarapan sangat penting karena memberikan kontribusi sebesar $15-25 \%$ dari total asupan sehari ${ }^{1}$. Asupan gizi anak yang melakukan sarapan lebih baik jika dibandingkan dengan anak yang tidak melakukan sarapan. Tidak sarapan akan menyebabkan defisit zat gizi dan tidak dapat menggantinya melalui waktu makan yang lain seperti makan siang dan makan malam ${ }^{2}$.

Sarapan merupakan hal sangat penting dilakukan karena sebagai energi awal pada saat kita akan melakukan berbagai macam aktivitas terutama untuk aktivitas yang berhubungan dengan fisik dan psikologis ${ }^{3}$. Berdasarkan penelitian yang dilakukan pada anak usia sekolah, mereka yang selalu menyempatkan sarapan sebelum berangkat ke sekolah mempunyai perkembangan motorik yang lebih baik dibandingkan dengan siswa yang tidak melakukan sarapan sebelum berangkat ke sekolah ${ }^{4}$.

Selain itu, sarapan membantu siswa untuk lebih berkonsentrasi dalam segala kegiatan yang akan dilakukannya. Kemampuan dalam memusatkan perasaan, pikiran, kemauan dan semua panca indera ke suatu objek dalam satu aktivitas tertentu, dan juga disertai dengan berbagai usaha untuk tidak memperdulikan obyek-obyek lain disekitarnya yang tidak memiliki hubungan dengan aktivitas yang dilakukan pada saat itu adalah pengertian dari konsentrasi ${ }^{5}$.

Untuk mengetahui seberapa cepat respon siswa dalam menerima stimulus dilakukan pengukuran waktu reaksi dengan menggunakan alat yang bernama Body Reaction. Menurut Bompa pengertian waktu reaksi adalah jarak antara diterimanya suatu stimulus terhadap respon gerak atau motorik yang dilakukan secara sadar yang ditandai dengan terjadinya reaksi otot atau gerakan yang pertama. Untuk mengetahui kecepatan respon motorik seseorang dalam menerima suatu stimulus perlu dilakukan pengukuran parameter fisiologi yaitu pengukuran waktu reaksi ${ }^{6}$. Kategori hasil intrepretasi pengukuran waktu reaksi dapat digolongkan dan dilihat pada Tabel $2^{7}$.

Sesuai dengan jenisnya, waktu reaksi dibagi menjadi 2 (dua) yaitu: waktu reaksi kompleks dan waktu reaksi sederhana. Waktu reaksi kompleks adalah waktu reaksi yang terjadi karena lebih dari 1 stimulus atau terdiri dari beberapa stimulus. Waktu reaksi sederhana adalah waktu reaksi yang berhubungan dengan kebiasaan dan merupakan jenis waktu reaksi yang banyak diaplikasikan dalam kehidupan sehari-hari, dalam penelitian ini seperti, kecepatan siswa dalam menerima respon atau dapat di ibaratkan dengan pelajaran seharihari disekolah yang diberikan.

Banyak faktor yang dapat mempengaruhi terjadinya waktu reaksi, antara lain yaitu usia, jenis kelamin, jenis stimulus, penggunaan tangan kanan atau kiri, latihan, status hidrasi, nutrisi dan faktor kelelahan. Jenis stimulus dapat mempengaruhi waktu reaksi. Jenis stimulus audio lebih cepat dan mudah untuk dipahami dan dilakukan jika dibandingkan dengan jenis stimulus visual dan jenis stimulus sentuhan ${ }^{4}$.

Hal ini disebabkan karena stimulus berupa audio atau suara memiliki waktu yang lebih cepat untuk menghantarkan stimulus ke otak dibandingkan dengan stimulus berupa gambar dan sentuhan. Waktu reaksi merupakan salah satu indikator yang dapat digunakan untuk mengukur tingkat kelelahan seseorang. Menurut Welfors bahwa waktu reaksi akan lebih lama apabila subjek atau seseorang sedang dalam kondisi kelelahan ${ }^{8}$.

Sarapan adalah salah satu yang memiliki kontribusi penting dalam memenuhi asupan gizi dalam sehari yang akan berdampak pada aktifitas yang akan dilakukan oleh seseorang dalam waktu tertentu. Penelitian ini bertujuan untuk mengetahui ada tidaknya perbedaan psikomotor waktu reaksi siswa yang memiliki kebiasaan sarapan dan tidak sarapan.

\section{METODE}

Penelitian cross sectional ini dilakukan di Madrasah Ibtidaiyah Islamiyah Desa Kramat Jegu Kabupaten Sidoarjo pada bulan Juli-Agustus tahun 2018. Sampel sejumlah 100 anak yang terdiri dari kelas 5 dan kelas 6 yang dipilih dengan menggunakan metode purposive sampling yaitu pemilihan responden berdasarkan keinginan peneliti, yaitu siswa yang mampu diajak berkomunikasi dengan baik. Data identitas pribadi responden, karateristik responden dan data kebiasaan sarapan responden didapatkan melalui wawancara dengan menggunakan kuesioner dan digolongkan kedalam kategori memiliki kebiasaan sarapan dan tidak sarapan berdasarkan frekuensi sarapan dalam satu minggu terakhir danjumlah asupan makan pada saat sarapan yang dihitung berdasarkan hasil recall $2 \times 24$ jam.

Waktu reaksi adalah jarak antara penerimaan suatu stimulus terhadap respon motorik yang dilakukan secara sadar, data waktu reaksi didapatkan dari hasil pengukuran menggunakan alat yang bernama Body Reaction. Hasil pengukuran waktu reaksi digolongkan ke dalam beberapa kategori, yaitu : Istimewa $(0,001-0,100$ detik), Bagus sekali $(0,101-0,200$ detik), Bagus $(0,201-$ 0,300 detik), Cukup/sedang (0,301 - 0,400 detik), Kurang $(0,401-0,500$ detik) dan Kurang sekali $(0,501$ detik - ke atas).

Pengukuran uji psikomotor waktu reaksi dilakukan pada pukul 09.00 - 11.00 baik untuk siswa yang sudah sarapan atau tidak sarapan pada hari itu.Pengukuran waktu reaksi dilakukan menggunakan alat dengan stimulus berupa audio atau suara. Sebelum dilakukan pengukuran, terlebih dahulu responden diberikan penjelasan mengenai bagaimana mekanisme 
cara penggunaan tombol pada alat Body Reaction. Sampel dipanggil sebanyak 10 anak dan diberikan penjelasan kemudian dilakukan pengukuran waktu reaksi, begitu seterusnya. Setiap subjek dilakukan pengukuran sebanyak 1 kali.

Analisis data dilakukan secara deskripstif dan analitik. Gambaran distribusi dapat dilihat dengan menggunakan analisis deskriptif, sedangkan analisis analitik untuk menganalisis ada tidaknya perbedaan antara kedua variabel diuji dengan menggunakan $\mathrm{Uji}$ Independent Sample T-Test. Komisi etik Fakultas Kesehatan Masyarakat Universitas Airlangga telah memberikan persetujuan dalam Penelitian ini dengan No : 456-KEPK.

\section{HASIL DAN PEMBAHASAN}

Responden dalam penelitian ini adalah siswa kelas 5 dan kelas 6, baik laki-laki ataupun perempuan. Sebagian besar responden berusia 11 tahun yaitu sebesar (60\%) dan 10 tahun sebesar (28\%), yang terdiri dari perempuan sebanyak 59 responden $(59 \%)$ dan lakilaki sebanyak 51 responden (41\%). Umur merupakan hal yang sangat penting dalam menentukan pemilihan jenis konsumsi, mulai dari kebutuhan konsumsi energi, protein, lemak, karbohidratdan zat gizi lainnya. Umur dapat mempengaruhi kecepatan seseorang dalam menerima dan merespon suatu informasi yang diterima selain itu merupakan salah satu faktor yang berhubungan dengan konsumsi makan ${ }^{9}$.

Berdasarkan Tabel 1 didapatkan hasil bahwa dari 100 responden sebesar $45 \%$ memiliki kategori sarapan dan sebesar $55 \%$ responden tidak sarapan. Responden dikatakan memiliki kebiasaan sarapan jika frekuensi sarapan dalam satu minggu adalah $\geq 6$ kali dan makanan yang dikonsumsi pada pagi hari sebesar $20-25 \%$ yang didapatkan hari perhitungan hasil recall selama $2 \times 24$ jam. Hal tersebut menunjukkan bahwa siswa yang tidak sarapan lebih banyak dibandingkan siswa yang sarapan.Banyak faktor yang menyebabkan siswa tidak sarapan seperti, bangun kesiangan, takut datang terlambat ke sekolah dan lauk yang monoton.

Tabel 1. Distribusi Responden berdasarkan

\begin{tabular}{lcc}
\multicolumn{2}{c}{ Karateristik } & \multicolumn{2}{c}{ Jumlah } \\
\hline \multirow{2}{*}{ Karateristik Responden } & $\mathbf{n}$ & $\begin{array}{c}\text { Persentase } \\
\text { (\%) }\end{array}$ \\
\cline { 2 - 3 } & $\mathbf{( 1 0 0 )}$ & \\
\hline $\begin{array}{l}\text { Jenis Kelamin Anak } \\
\quad \text { Perempuan } \\
\text { Laki-laki }\end{array}$ & 59 & 59 \\
& 41 & 41 \\
Umur Anak & & \\
9 tahun & & 1 \\
10 tahun & 1 & 28 \\
11 tahun & 28 & 60 \\
12 tahun & 60 & 11 \\
& 11 & \\
Kebiasaan Sarapan & & 45 \\
Sarapan & & 55 \\
Tidak Sarapan & 45 & \\
\hline
\end{tabular}

Hasil tersebut masih lebih kecil dibandingkan dengan penelitian yang dilakukan olehlrma Yunawati (2015) pada anak sekolah di daerah Nusa Tenggara Timur, dalam penelitian tersebut sebanyak $80 \%$ anak sarapan sebelum berangkat ke sekolah ${ }^{10}$. Sedangkan menurut penelitian yang dilakukan oleh Munik Mbarwati (2014), bahwa sebanyak 47,8\% siswa di SDN Banyanyar III memiliki kebiasaan sarapan ${ }^{11}$.

Sarapan yang baik harus banyak mengandung karbohidrat yang akan digunakan untuk membantu merangsang glukosa dan mikronutrient lainnya dalam otak sehingga dapat menghasilkan energi, kemudian energi tersebut dapat memacu otak untuk membantu memusatkan pikiran untuk belajar dan memudahkan dalam penyerapan pelajaran ${ }^{12}$. Sarapan sangat bermanfaat karena dapat memberikan nutrisi otak pertama kali di awal hari atau pagi hari sehingga dapat meningkatkan kemampuan otak dan membantu agar lebih mudah untuk berkonsentrasi ${ }^{13}$. Banyak manfaat dari pemenuhan sarapan pagi. Manfaat-manfaat tersebut antara lain adalah peningkatan prestasi dan konsentrasi pada siswa.

Konsentrasi dipengaruhi oleh asupan energi yang didapatkan dari makan pagi dan kandungan gizi pada makan pagi tesebut. Sarapan sangat penting bagi tubuh karena lambung akan terisi kembali setelah 8-10 jam kosong saat malam hari dan kadar gula akan menurun sehingga pasokan energi menuju otak akan terganggu. Glukosa adalah nutrisi yang ada pada sarapan yang berperan penting untuk aktivitas otak ${ }^{14}$. Karbohidrat yang didapatkan dari sarapan akan berfungsi untuk merangsang glukosa dan mikronutrient lain yang ada di dalam otak yang dapat menghasilkan energi. Selain itu dapat berfungsi untuk memacu otak agar lebih mudah untuk memusatkan pikiran untuk belajar dan memudahkan dalam menyerap pelajaran ${ }^{12}$.

Banyak penelitian yang membahas tentang pentingnya sarapan, antara lain hubungan sarapan dengan prestasi belajar, hubungan sarapan dengan status gizi, hubungan sarapan dengan faktor kognitif, faktor-faktor yang mempengaruhi kebiasaan sarapan dan masih banyak lagi. Menurut penelitian yang dilakukan oleh Caroline (2005) tentang pengaruh sarapan pada proses kognitif pada anak sekolah dasar menunjukkan bahwa dengan sarapan dapat mempengaruhi kinerja kognitif anak-anak pada beberapa langkah-langkah, terutama memori spasial, memori jangka pendek dan perhatian pendengaran ${ }^{15}$. Karena belum ada penelitian kepada anak sekolah dasar tentang hubungan sarapan dan motorik siswa, maka dilakukan penelitian tentang uji psikomotor waktu reaksi yang pada siswa yang sarapan dan tidak sarapan.

Gizi seimbang merupakan aspek penting dalam perkembangan fisik dan motorik yang dapat dilakukan dengan cara pemberian makanan. Makanan yang memenuhi gizi seimbang yaitu makanan yang mengandung energi, karbohidrat, protein serta lemak adalah makanan yang dikenal di Indonesia.Jika anak mengalami kekurangan gizi maka perkembangan fisiknya akan terhambat begitu pula motoriknya. 
Sarapan yang baik adalah sarapan yang memiliki kualitas dan kuantitas makanan yang baik yaitu sebesar 20-35\% dari kecukupan energi harian ${ }^{16}$. Hal ini sejalan dengan penelitian yang dilakukan pada anak-anak sekolah dan hasilnya menunjukkan bahwa anak yang sarapan sebelum berangkat ke sekolah secara teratur mempunyai fungsi motorik yang lebih baik dibandingkan dengan mereka yang tidak teratur makan pagi atau tidak sarapan 4 .

Tidak melakukan sarapan akan menyebabkan tubuh kekurangan glukosa dan akan menyebabkan tubuh menjadi lemah sehingga sulit untuk berkonsentrasi karena tidak adanya pasokan energi dari dalam tubuh. Hal tersebut adalah hipoglikemi yaitu kondisi dimana tubuh kekurangan glukosa karena tidak ada cadangan glukosa dalam tubuh, sehingga tubuh akan membongkar persediaan energi yang diambil dari jaringan lemak tubuh ${ }^{17}$.

Sarapan dapat memperpendek psikomotor waktu reaksi karena kecepatan dan konsistensi waktu reaksi juga dipengaruhi oleh beberapa faktor, dan faktor sarapan termasuk salah satunya ${ }^{18}$. Setelah dilakukan pengukuran waktu reaksi kepada responden didapatkan hasil uji waktu reaksi yang hasilnya digolongkan ke dalam beberapa kategori. Data hasil uji psikomotor waktu reaksi responden tersebut disajikan pada Tabel 2.

Berdasarkan Tabel 2 dapat diketahui bahwa sebagian besar hasil uji psikomotor responden memiliki kategori kurang sekali dengan nilai (0,501 detik -ke atas) sebanyak 65 anak dan kategori cukup/sedang dengan nilai $(0,301-0,400$ detik) sebanyak 17 anak. Dari total 100 sampel yang dilakukan pengukuran waktu reaksi didapatkan nilai rata-rata hasilnya adalah 1,132 detik dengan nilai maksimum 5,357 detik dan nilai minimum 0,107 detik.

Banyak faktor yang dapat mempengaruhi waktu reaksi, antara lain jenis adalah kelamin, usia, jenis stimulus, penggunaan tangan kanan atau kiri, latihan, status hidrasi, nutrisi dan faktor kelelahan. Faktor yang berperan dalam hal ini adalah kelelahan, mengingat pada saat penelitian dilakukan bertepatan dengan pelaksanaan lomba dalam rangka memperingati hari kemerdekaan Republik Indonesia dan siswa yang menjadi responden ikut berpartisipasi dalam lomba tersebut.

Pada pengukuran ke 1 sampai dengan 4 kondisi siswa masih dalam keadaan baik mengingat mereka belum mengikuti lomba. Sedangkan untuk pengukuran ke 5 sampai dengan 10 siswa dalam keadaan lelah karena mereka mengikuti lomba sebelum diadakan pengukuran. Selain itu faktor lain yaitu kebisingan, pengukuran dilakukan di lantai 2 ruang kelas, namun di bawah atau di lapangan sedang berlangsung lomba sehingga secara tidak langsung suara-suara siswa yang lain terdengar dan konsentrasi responden secara tidak langsung akan terganggu.

Konsentrasi dapat dipengaruhi oleh glukosa. Glukosa didapatkan dari makanan yang dikonsumsi salah satunya saat pagi hari atau saat sarapan.Komposisi yang ada dalam makanan dapat mempengaruhi fungsi motorik dan kognitif melalui saluran pencernaan. Pemenuhan nutrisi sangat penting yaitu berperan untuk mengaktifkan daya kerja tubuh sehingga tubuh tidak mudah lelah salah satunya yaitu dengan melakukan sarapan $^{19}$. Hasil penelitian ini sejalan dengan penelitian sebelumnya yang dilakukan di SDN Wonocatur dan SDN Sumberejo 1 Kabupaten Kediri tentang sarapan dan hasil dari penelitian tersebut menjelaskan bahwa sarapan dengan daya konsentrasi pada siswa usia sekolah adalah dua hal yang sangat berkaitan atau ada hubungan ${ }^{20}$.

Pada Tabel 2 menggambarkan bahwa siswa yang memiliki kebiasaan sarapan mempunyai hasil uji psikomotor waktu reaksi dengan kategori cukup yaitu sebesar $26,7 \%$, kategori bagus sebesar $15,6 \%$, bagus sekali sebesar $4,44 \%$ dan istimewa sebesar $2,22 \%$. Jumlah tersebut lebih baik dibandingkan dengan kategori waktu reaksi yang dimiliki siswa yang tidak memiliki kebiasaan sarapan.

Berdasarkan hasil statistik uji beda tersebut menunjukkan adanya perbedaan uji psikomotor waktu reaksi antara siswa yang memiliki kebiasaan sarapan dan tidak sarapan yang ditunjukkan dengan hasil uji $P=0,01$. Hal tersebut menggambarkan bahwa siswa yang memiliki kebiasaan sarapan memiliki uji psikomotor yang lebih baik dibandingkan yang tidak sarapan.

Tabel 2. Distribusi Uji Psikomotor Waktu Reaksi Berdasarkan Kebiasaan Sarapan

\begin{tabular}{|c|c|c|c|c|c|c|}
\hline \multirow{3}{*}{ Kategori Waktu Reaksi } & \multicolumn{4}{|c|}{ Kebiasaan Sarapan } & \multirow{2}{*}{\multicolumn{2}{|c|}{ Total }} \\
\hline & \multicolumn{2}{|c|}{ Sarapan } & \multicolumn{2}{|c|}{ Tidak Sarapan } & & \\
\hline & $\mathrm{n}$ & $\%$ & $\mathbf{n}$ & $\%$ & $\mathrm{n}$ & $\%$ \\
\hline Istimewa $(0,001-0,100$ detik) & 0 & 0 & 0 & 0 & 0 & 100 \\
\hline Bagus sekali $(0,101-0,200$ detik) & 2 & 66,7 & 1 & 33,3 & 3 & 100 \\
\hline Bagus $(0,201-0,300$ detik $)$ & 7 & 70 & 3 & 30 & 10 & 100 \\
\hline Cukup/sedang $(0,301-0,400$ detik) & 12 & 70,6 & 5 & 29,4 & 17 & 100 \\
\hline Kurang $(0,401-0,500$ detik $)$ & 3 & 60 & 2 & 40 & 5 & 100 \\
\hline Kurang sekali $(0,501$ detik - ke atas) & 21 & 32,3 & 44 & 67,7 & 65 & 100 \\
\hline
\end{tabular}

Tabel 3. Uji Psikomotor Waktu Reaksi Berdasarkan Kebiasaan Sarapan

\begin{tabular}{lccc}
\hline \multicolumn{1}{c}{ Waktu Reaksi } & Sarapan & Tidak Sarapan & p \\
\hline Rata-rata \pm SD & $0,909 \pm 0,999$ detik & $1,314 \pm 0,915$ detik & $0,01^{*}$
\end{tabular}


Hal tersebut sejalan dengan penelitian yang pernah dilakukan oleh Mahasiswa Kedokteran Universitas Udayana, Ngurah Wisnu Nayaka (2012) dalam penelitiannya didapatkan hasil bahwa pemberian sarapan kepada siswa dapat mempercepat psikomotor waktu reaksi ${ }^{21}$. Hasil penelitian tersebut didukung pula oleh dengan penelitian yang dilakukan oleh Valeria dkk, menunjukkan bahwa dengan sarapan akan berpengaruh terhadap fungsi kognitif dan psikomotor.

Pemberian intervensi berupa sarapan dapat mempercepat waktu reaksi pada subjek secara signifikan. Sarapan akan menyebabkan tekanan postpondial secara signifikan saat mengeluarkan energy, hal tersebut akan memperpendek waktu reaksi ${ }^{18}$. Dengan melakukan sarapan akan mengoptimalkan proses glukolisis di dalam tubuh sehingga dapat mengatasi masalah hipoglikemia dan deplesi glikogen pada otot. Hal ini akan mempengaruhi kecepatan hantaran impul dari aferan ke otak. Hantaran impul ini akan lebih cepat tersampaikan dengan adanya energi yang optimal sehingga secara otomatis waktu reaksi akan lebih cepat. Dengan sarapan yang maksimal diharapkan adanya energi yang optimal pula sehingga pemberian stimulus dalam hal ini pemberian materi pada saat pelajaran dapat diterima oleh responden atau siswa.

Glukosa merupakan sumber energi utama yang digunakan untuk kerja otak. Glukosa-6-fosfat yang ada di hati akan diubah menjadi glukosa sehingga kadar glukosa dalam darah akan meningkat. Sedangkan jaringan lain yang tidak memilikii enzim glukosa-6-fosfatase tidak akan dapat mengubah glukosa 6 fosfat menjadi glukosa. Apabila persediaan glukosa dalam darah menurun, organ hati akan mengubah sebagian dari glikogen menjadi glukosa kemudian dan akan mengeluarkannya ke aliran darah. Glukosa inilah yang akan diedarkan oleh darah ke seluruh bagian tubuh yang memerlukan, salah satunya adalah ke otak 22

\section{KESIMPULAN}

Kesimpulan dari penelitian ini adalah siswa yang melakukan sarapan pagi akan lebih cepat menerima respon atau stimulus yang diberikan. Dengan demikian diharapkan agar sebelum berangkat ke sekolah, anak menyempatkan untuk sarapan terlebih dahulu.

\section{ACKNOWLEDGEMENT}

Penulis mengucapkan terimakasih kepada Madrasah Ibtidaiyah Islamiyah, Sidoarjo yang telah memberikan izin untuk dijadikan sebagai tempat berlangsungnya penelitian ini, seluruh murid khususnya kelas 5 dan 6 yang telah bersedia menjadi responden dalam penelitian ini.

\section{REFERENSI}

1. Khomsan, A. Pangan dan Gizi Untuk Kesehatan 2. (Departemen Gizi Masyarakat, Fakultas Ekologi Manusia, Institut Pertanian Bogor, 2005).
2. Rampersaud G., Pereira M., Girard B., Adams J., Metzl., J. Breakfast habits, nutritional status, body weight, and academic performance in children and adolescents. J Am Diet Assoc.105, 74-60 (2005).

3. Gurdani Y. Kebiasaan Makan Pagi, Lama Tidur Dan Kelelahan Kerja (Fatique) Pada Dosen. J. Kesehat. Masy. 53-7 (2003).

4. Baldiger, N., Krebs, A., Muller, R., \& A. Swiss Children Consuming Breakfast Regulary Have Better Motor Functional Skills and Are Less Overweight Than Breakfast Skippers. J. Am. Coll. Nutr.2, 87-93 (2012).

5. Larega, T. S. P. Effect Of Breakfast On The Level Of Concentration In Adolescents. J Major.4, 115121 (2015).

6. Bompa, T., \& Harf, G. Periodization Training for Sports:Theory and Methodelogy of Training. (Human Kinetics, 2009).

7. Hendriawan, I. Hubungan Whole Body Reaction Time Dengan Antisipasi Penjaga Gawang Pada Saat Tendangan Penalty Dalam Olahraga Sepakbola. (Universitas Pendidikan Indonesia, 2014).

8. Brebner, J.T \& Welford, A. . Introduction:An Historical Background Sketch In Welford Reaction Time. (Academic Press, 1980).

9. Kurniasih, D. Hilmansyah, H. Astuti, MP. Imam, S. Sehat dan Bugar Berkat Gizi Seimbang. (Gramedia, 2010).

10. Yulianti, I., Hadi, H. \& Julia, M. Kebiasaan Sarapan tidak berhubungan dengan Status Gizi Anak Sekolah Dasar di Kabupaten Timor Tengah Selatan Provinsi Nusa Tenggara Timur. J. Gizi dan Diet. Indones. 3, 77-86 (2015).

11. Ambarwati, M. Hubungan Antara Pengetahuan, Sikap dan Kebiasaan Makan Pagi dengan Status Gizi Anak di SDN Banyuanyar III Kota Surakarta. (Universitas Muhammadiyah Surakarta, 2014).

12. Moehji. Ilmu Gizi 2 Penanggulangan Gizi Buruk. (PT. Bharata Niaga Media, 2009).

13. Prabowo, Y. Hubungan Antara Kebiasaan Sarapan Pagi Dengan Indeks Prestasi Kumulatif (IPK) Mahasiswa Tingkat III Fakultas Kedokteran UPN 'Veteran' Jakarta Tahun Ajaran 2010-2011. (Universitas Veteran Jakarta, 2011).

14. Ackuaku-Dogbe, E. \& Abaidoo, B. Breakfast Eating Habits among Medical Students. Ghana Med. J.48, 66 (2014).

15. Mahoney, C. R., Taylor, H. A., Kanarek, R. B. \& Samuel, P. Effect of Breakfast Composition on Cognitive Processes in Elementary School Children. Physiol. Behav.85, 635-645 (2005).

16. Giovanni, M. Breakfast: a Good Habit, Not Repetitive Custom. J. Int. Med. Res.36, 613-624 (2008).

17. Masithah, T. \& Martianto, D. Hubungan Pola Asuh Makan dan Kesehatan Dengan Status Gizi Anak Batita Di Desa Mulya Harja. Media gizi dan Kel.29, 29-39 (2005).

18. Maffeis, C. Breakfast Skipping In Prepubertal Obese Children : Hormonal Metabolic and 
Cognitive Consequences. Eur. J. Clin. Nutr.66, 314-321 (2012).

19. Hidayat, A. Manfaat Sarapan. (Erlangga, 2011).

20. Wardoyo, H. A. \& Mahmudiono, T. Hubungan Makan Pagi dan Tingkat Konsumsi Zat Gizi dengan Daya Konsentrasi Siswa Sekolah Dasar. Media Gizi Indones.9, 49-53 (2013).

21. Putra, A. . N. W. N. \& Muliarta, M. Pemberian
Sarapan Mempercepat Waktu Reaksi pada Mahasiswa Fakultas Kedokteran Universitas Udayana. (Universitas Udayana, 2015).

22. Gajre, N.S, Fernandez, S.Balakrishna, N., Vazir, S. Breakfast Eating Habit and its Influence on Attention-concentration, Immediate Memory and School Achievement. Indian Pediatr. J. (2008). 